\title{
IMPORT OF NOROVIRUS INFECTIONS IN THE NETHERLANDS AND IRELAND FOLLOWING PILGRIMAgES TO LOURDES, 2008 - PRELIMINARY REPORT
}

\author{
L Verhoef (linda.verhoef@rivm.nl) ${ }^{1}$, E Duizer ${ }^{1}$, H Vennema ${ }^{1}$, J Siebenga ${ }^{1}$, Corine Swaan ${ }^{1}$, L Isken ${ }^{1}$, M Koopmans $^{1}, K_{\text {Kalay }}^{2}$, \\ P Pothier ${ }^{2}$, Paul McKeown ${ }^{3}, \mathrm{G}$ van Dijk ${ }^{4}$, P Capdepon ${ }^{5}$, G Delmas ${ }^{6}$ \\ 1. National Institute for Public Health and the Environment, Center for Infectious Disease Control, Bilthoven, the Netherlands \\ 2. National Reference Centre for Enteric Viruses, Dijon, France \\ 3. Health Protection Surveillance Centre, Dublin, Ireland \\ 4. Municipal Health Service West-Brabant, Breda, the Netherlands \\ 5. Direction Départementale des Affaires Sanitaires et Sociales (District Health and Social Services, DDASS) des Haute Pyrénées, \\ France \\ 6. Institut de Veille Sanitaire (French Institute for Public Health Surveillance, INVS), Saint Maurice, France
}

Between mid-September and 19 October 2008, nine clusters of norovirus infection involving around 90 primary cases and over a hundred secondary cases were identified in patients from the Netherlands, Ireland, Italy and France, linked to pilgrimage to Lourdes, France.

\section{Introduction}

Norovirus is a highly infectious causative agent of acute gastroenteritis (AGE). Transmission can easily occur through contact with people shedding the virus, through consumption of contaminated food or water, through contaminated aerosols resulting from vomiting, and through environmental contamination [1]. Once the virus is introduced in settings with a high concentration of people, person-to-person transmission is likely to occur [2]. Attack rates are high among all groups of people, however, the impact of the disease is more serious among the elderly [3]. Within Europe, norovirus outbreaks are monitored by the Food-borne Viruses in Europe (FBVE) network, which has been collecting molecular and epidemiological data since 1999 [4].

Lourdes, France, is a major destination for Christian pilgrimage following claims of apparitions in 1858. A yearly number of five million people, including many with underlying diseases, visit Lourdes and often collect spring water for consumption, which is believed to possess healing properties. With 2008 being the 150th anniversary of the apparitions, the number of visitors has increased to eight million this year, with a peak in visitor numbers around the time of the Pope's visit. Norovirus outbreaks have previously been linked to pilgrimage to Lourdes in 2002 [5, FBVE unpublished data].

Outbreak report

On 20 October 2008, the FBVE network was notified of an outbreak due to norovirus in a mental health care institution for the elderly in the Netherlands, that had serious consequences. Norovirus was confirmed in two patients.
A group of 10 patients and 14 health workers at the institution had visited Lourdes between 26 September and 1 October as part of a group of 1,025 Dutch pilgrims. On 29 September, one of the health workers started showing symptoms of AGE that lasted 24 hours and made it necessary that she stayed in the hotel room. During the return trip by train on 1 October, one of the patients in the group became symptomatic and required medical assistance. After the group had returned to the Netherlands, the virus spread within the institution.

A total of 119 of the 550 institutionalised patients and health care workers (22\%) showed AGE symptoms. At the time of publication of this report, the outbreak was still ongoing due to difficulties in compliance with the control measures in this particular group of patients. Four people (3\%) died during this outbreak, with norovirus reported as a contributing factor. One patient is still hospitalised and in critical condition.

Norovirus infection is not a notifiable disease in the Netherlands unless outbreaks occur in institutions. As information form the Dutch organisation that facilitated the trip indicated that more pilgrims were returning from Lourdes with symptoms of AGE, the Center of Infectious Disease Control (RIVM/CIb) requested the Municipal Health Services and microbiologists to report norovirus infections related to Lourdes. This resulted in three more AGE notifications: two clusters of Dutch pilgrims who had visited Lourdes between 16 and 23 September, one of which led to secondary cases in the patient's family, and an elderly pilgrim with confirmed norovirus infection who required hospitalisation 32 hours after returning from Lourdes on 18 October. RT-PCR and subsequent sequencing of parts of the polymerase (region A) and VP1 capsid (region D) genes identified this strain as the widely detected genotype II.4 2006 b variant.

Other cases related to this outbreak

An alert within the FBVE-network revealed that other outbreaks of AGE with a link to Lourdes had been reported. Ireland noted three clusters of norovirus infections: 
- one involving 40 patients infected in Lourdes in late September,

- one involving 20 cases infected in Lourdes between 1 and 15 October,

- and one cluster involving two cases infected in Lourdes between 1 and 15 October, one of whom required hospitalisation and caused 11 secondary cases in the hospital.

\section{Epidemiological investigation}

Local investigation by the French Institute for Public Health Surveillance (InVS) pointed out that at least six hotels with Dutch, French and Italian visitors were coping with AGE patients, who may include two Dutch clusters and one Irish cluster, in the period between 28 September and 16 October. Laboratory tests were done in France and norovirus was confirmed in three people, housed in three different hotels that experienced outbreaks: two samples from Dutch patients and one sample from a French patient. All three samples were found to be positive for the genotype II.4 2006b variant, with the sequence of region $A$ and parts of the capsid gene identical to the one detected in the Dutch cases described above, but also to isolates found in outbreaks not linked to Lourdes.

To summarise, around 90 primary cases of AGE were reported in Lourdes, belonging to seven different pilgrim groups from the Netherlands, Ireland, Italy and France, resulting in more than a hundred secondary cases. These groups were housed in six hotels in Lourdes between mid-September and 16 October. Physicians and pharmacists in Lourdes reported a small peak in diarrhoea consultations between 22 and 26 September, coinciding with the peak in the number of pilgrims related to the Pope's visit.

The French district health office regularly checks the bacteriological quality of the tap and spring water in Lourdes, which were both in accordance with the required standards.

\section{Discussion}

In this rapid communication we report one single case in the Netherlands and at least nine clusters of AGE that occurred between mid-September and 19 October 2008 following pilgrimage to Lourdes: three clusters in the Netherlands, three in Ireland, and six in France, of which three are possibly overlapping. One case/ cluster and four clusters were tested by RT-PCR, and noroviruses of a commonly detected genotype were found in all of these patients. One of the confirmed clusters led to a large outbreak in a mental health institution that is still ongoing. The substantial attack rate and case fatality rate in this institution reflects the vulnerability of the patient group in which the virus was introduced.

Although detailed information on the source of exposure is not (yet) available, person-to-person spread is likely to be the most important route of transmission in this outbreak, given the large numbers of people visiting Lourdes and the health condition of the exposed population, since it is mainly people with delicate health who visit the site for its healing properties In 2002, a comparable situation was reported from Switzerland [5]. Once norovirus is introduced in settings with high concentrations of people, environmental contamination is likely to occur, for example due to projectile vomiting, which is an effective transmission route [6]. Furthermore, introduction of the virus through food or water cannot be ruled out. The spring water that is drunk by the pilgrims was approved according to bacteriological quality standards, but this does not exclude the presence of viruses $[7,8]$. Information on locations visited by the cases in the days before their illness will be collected to support France in the outbreak investigation.
It is of interest to know whether norovirus continues to circulate among pilgrims in Lourdes. If so, travel agencies and visitors should be informed to be able to take preventive measures around any visitor showing symptoms of AGE during their stay in or returning from Lourdes. The latter is particularly important if the traveller lives among fragile people, for instance in a nursing home or hospital. Hotels housing vulnerable people should be alert when visitors show symptoms of AGE.

To determine whether the outbreak is still ongoing in Lourdes, and to determine the consequences of this outbreak, the FBVE network is interested in laboratory specimens of related cases. If you have any additional information on confirmed cases linked to Lourdes, please contact fbve@rivm.nl.

\section{References}

1. Duizer E, Koopmans M. Tracking emerging pathogens: the case of noroviruses In: Motarjemi Y, Adams M, editors. Boca Raton: Woodhead publishing limited; 2006. p. 77-110.

2. Kroneman A, Verhoef $L$, Harris J, Vennema $H$, Duizer $E$, van Duynhoven $Y$, et al Analysis of integrated virological and epidemiological reports of norovirus outbreaks collected within the foodborne viruses in Europe Network from 1 July 2001 to 30 June 2006. J Clin Microbiol. 2008;46(9):2959-65.

3. van Asten L, van den Wijngaard C, Siebenga J, van Pelt W, van Vliet H, Koopmans M. Greater pathogenecity of norovirus strains in 2003? A syndromic approach. Advances in Disease Surveillance. 2007;2:175.

4. Koopmans M, Vennema H, Heersma H, van Strien E, van Duynhoven Y, Brown D, et al. Early identification of common-source foodborne virus outbreaks in Europe. Emerg Infect Dis. 2003;9(9):1136-42.

5. Fretz R, Schmid H, Kayser U, Svoboda P, Tanner M, Baumgartner A. Rapid propagation of norovirus gastrointestinal illness through multiple nursing homes following a pilgrimage. Eur $\mathrm{J}$ Clin Microbiol Infect Dis. 2003;22(10):625-7.

6. Marks PJ, Vipond IB, Carlisle D, Deakin D, Fey RE, Caul EO. Evidence for airborne transmission of Norwalk-like virus (NLV) in a hotel restaurant. Epidemiol Infect. 2000;124(3):481-7.

7. Koopmans M, Duizer E. Foodborne viruses: an emerging problem. Int J Food Microbiol. 2004;90(1):23-41.

8. Prato R, Lopalco PL, Chironna M, Barbuti G, Germinario C, Quarto M. Norovirus gastroenteritis general outbreak associated with raw shellfish consumption in south Italy. BMC Infect Dis. 2004:4:37.

This article was published on 30 October 2008.

Citation style for this article: Verhoef L, Duizer E, Vennema H, Siebenga J, Swaan C, Isken L, Koopmans M, Balay K, Pothier P, McKeown P, van Dijk G, Capdepon P, Delmas G. Import of norovirus infections in the Netherlands and Ireland following pilorimages to Lourdes, 2008 - preliminary report. Euro Surveill. 2008:13(44):pij=19025. Available online: http://www.eurosurveillance.org/ViewArticle.aspx?ArticleId $=19025$ 